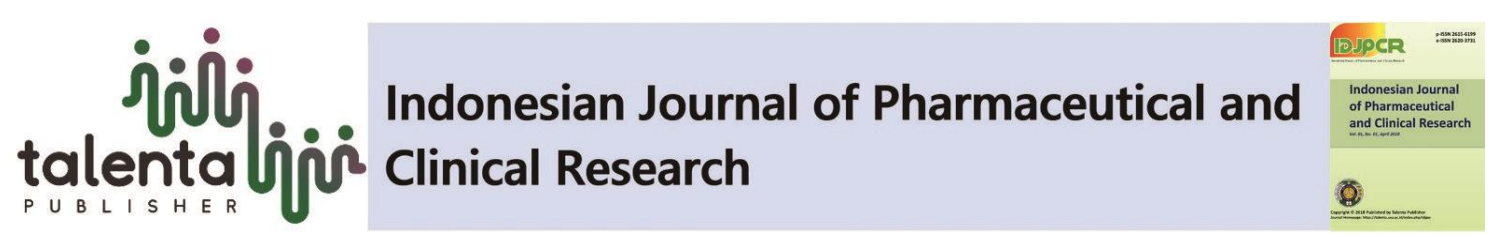

\title{
Formulation of Antiacne Cream Dosage Form Containing Mangosteen (Garcinia mangostana L.) Pericarp Ethanolic Extract
}

\author{
Supomo $^{1 *}$, Anita Apriliana ${ }^{1}$, Titin Purnawati ${ }^{1}$, AinurRisqi ${ }^{1}$ \\ ${ }^{1}$ Akademi Farmasi Samarinda,Samarinda, Indonesia
}

\begin{abstract}
The aim of this study was to formulate ethanolic extract of mangosteen (Garcinia mangostana L.) pericarp (EEMP) in the antiacne cream dosage form. The formulae were made with 3 varied concentrations of $0.5 \%, 1.5 \%$ and $4.5 \%$. The tests carried out in this study were organoleptic cream preparations (odor, color, texture), homogeneity, $\mathrm{pH}$, determination of the type of cream, spreadability, and the antibacterial activity against Staphylococcus epidermidis. The results of physical property evaluations showed that the EEMP indicated the $\mathrm{pH}$ value of 6 , the spredability of the cream increased along with the increasing length of storage time. Duncan Test on the measurement of diameter dispersibility based on storage time showed that there were significant differences between the spreadability of the cream B and C. The cream produced was easy to wash indicating oil in water $(\mathrm{o} / \mathrm{w})$ type. The results of antibacterial activity test applying agar diffusion method using Mueller Hinton medium Agar (MHA) indicated that the inhibition zones of formulae II and III were 5.2 and $6 \mathrm{~mm}$, respectively. Whereas, the formula I as well as the negative control showed no inhibition zones. It can be concluded that the EEMP can be formulated as an antiacne cream. The best cream formula was the formula II with the results of physical properties test were quite stable and able to produce inhibition zone against Staphylococcus epidermidis.
\end{abstract}

Keywords: Garcinia mangostana, cream, antiacne, antibacterial, Staphylococcus epidermidis.

Abstrak. Penelitian ini bertujuan untuk memformulasi ekstrak etanol kulit manggis (EEKM) (Garcinia mangostana L.) dalam bentuk sediaan krim anti jerawat. Formula dibuat dengan 3 variasi konsentrasi ekstrak yaitu 0,5\%, 1,5\% and 4,5\%. Pengujiandilakukan terhadap organoleptis krim (bau, warna, tampilan), homogenitas, pH, tipe krim, kemudahan pemakaian, dan pengujian aktivitas sebagai antibakteri terhadap Staphylococcus epidermidis. Hasil pengujian karakteristik fisik menunjukkan bahwa EEKM mempunyai pH 6. Kemampuan menyebar meningkat sejalan dengan lama penyimpanan. Hasil uji Duncan terhadap kemampuan penyebaran menunjukkan perbedaan yang signifikan antara krim $B$ dan krim $C$. Krim yang dihasilkan mudah dicuci menandakan bahwa krim merupakan tipe minyak dalam air. Hasil yang ditunjukkan pada pengujian anti bakteri menggunakan metode difusi agar dengan media Mueller Hilton Agar (MHA) menunjukkan bahwa zona hambatan formula II dan III masing-masing 5,2 dan 6 mm. Di sisi lain, formula I dan kontrol negatif tidak menghasilkan zona hambatan. Dapat disimpulkan bahwa EEKM dapat diformulasikan menjadi krim anti jerawat. Formula krim yang terbaik adalah formula II dengan stabilitas yang memadai dan mampu menghambat pertumbuhan bakteri Staphylococcus epidermidis.

*Corresponding author at: Akademi Farmasi Samarinda,Samarinda, Indonesia

E-mail address: fahmipomo@gmail.com 
Kata kunci: Garcinia mangostana, krim, anti jerawat, anti bakteri, Staphylococcus epidermidis.

Received 15 June 2017 | Revised 4 October 2017 | Accepted 12 March 2018

\section{Introduction}

Acne (acne vulgaris) is one of the most common skin disease and affects $85-100 \%$ of people at some time during their life. The acne affects the areas of the skin that have a lot of sebaceous follicles(oil glands), such as the face, upper chest and back. Acne is not limited to teens. As many as $12 \%$ of women and $5 \%$ of men at age of 25 have acne problems. After the age of 45 , $5 \%$ of both men and women still have acne problems.

The cause of acne is not completely known but it is definitely caused by multi factors. These factors include genetics, race, menstruation, birth control pills, endocrine, food, seasonal psychiatric (mental) disorders, bacterial infection and cosmetics [1]. The common bacteria cause acne include Propionibacterium acnes and Staphylococcus epidermidis[2]. Staphylococcus epidermidis is a Gram-positive bacteria commonly found in acne lesions. Staphylococcus epidermidis can hydrolyze triglycerides into free fatty acids and glycerol, free fatty acids allows the lesions getting more severe [3].

The use of mangosteen as a traditional medicine has been studied by scientists.For example, a study carried out by Chomnawang et al., (2005), showed that mangosteen has antibacterial activity against Propionibacterium acnes and Staphylococcus epidermidis [4]. Then Chomnawang et al., in 2007, did a research on various tropical plants of Thailand, one of them was the fruit of the mangosteen (Garcinia mangostana L.). These studies showed that the ethanolic extract of mangosteen pericarp reduced and inhibited inflammation caused by Propionibacterium acnes [5]. Subsequently, in 2008, Pothitirat, et al, through their research also proved that the ethanolic extract of mangosteen pericarp had effective antibacterial activity against $P$. acnes and $S$. epidermidis bacteria. Phytochemical screening of chemical compounds of mangosteen pericarpshowed that this part contained alkaloids, saponins, tannins, and flavonoids and able to produce inhibition zone against Staphylococcus epidermidis[6].

This study was done to improve the use of the plants, especially on the mangosteen pericarp. In addition, the formulation of the ethanolic extract of mangosteen pericarp into cream as antiacne dosage form can be scaled-up to the manufacturing production of cosmetics that offer advantages as a cosmetic with active ingredients derived from natural materials. 


\section{Methods}

The method used in this study was the experimental method, a method that tests a hypothesis in order to find the influences, relationships and differences imposed changes to the treatment group. Stages of the research included sample collection, sample processing, mangosteen pericarp extraction, base cream preparation, cream preparation containing ethanolic extract of mangosteen pericarp and evaluation of cream dosage forms containing the extract.

\subsection{Determination of Mangosteen}

The determination of the plant was performed by the Laboratory of Physiology, Faculty of Mathematics and Natural Sciences, Mulawarman University.

\subsection{Extraction of Mangosteen Pericarp}

The extraction method used was maceration which is a way of withdrawal of active substances that do not use heat, so the compounds contained in the mangosteen pericarp can be kept stable and protected from damage due to heat during the extraction process. In addition, the apparatus and equipment in the maceration process are relatively simple [7].

The solvent used in the preparation of the extract was ethanol 95\%. This solvent had been selected due to its properties, such as selective, non-toxic, neutral, good absorption, the produced extract was is not easily covered with mold and bacteria, and could be mixed with water in any effective ratio to produce the optimum amount of active ingredient [7].

\subsection{Formulation of Mangosteen Pericarp Ethanolic Extract Cream}

The cream formulae were prepared in various concentrations of mangosteen pericarp ethanolic extract, stearic acid and triethanolamine. Variations in the concentration of the extract used was based on the researchs of Sukatta (2008) and Poeloengan (2010), so that the smallest concentration taken was $0.5 \%$ and the highest was $4.5 \%[2,8]$. Pothitirat (2008) also stated that the concentration of the mangosteen pericarp ethanolic extract $>5 \%$ was able to withdraw good antiacne components [6]. 
Table 1. Formulae of Antiacne Mangosteen Rind Ethanolic Extract

\begin{tabular}{lccc}
\hline \multicolumn{1}{c}{ Material } & Formula1 & Formula 2 & Formula3 \\
\hline Mangosteen Pericarp & $0.05 \mathrm{~g}$ & $0.15 \mathrm{~g}$ & $0.45 \mathrm{~g}$ \\
Ethanolic Extract & $1.45 \mathrm{~g}$ & $1 \mathrm{~g}$ & $1 \mathrm{~g}$ \\
Stearic acid & $0.15 \mathrm{~g}$ & $0.2 \mathrm{~g}$ & $0.25 \mathrm{~g}$ \\
Triethanolamine & $0.3 \mathrm{~g}$ & $0.3 \mathrm{~g}$ & $0.3 \mathrm{~g}$ \\
Adeps lanae & $2.5 \mathrm{~g}$ & $2.5 \mathrm{~g}$ & $2.5 \mathrm{~g}$ \\
Paraffin liquid & $0.03 \mathrm{~g}$ & $0.03 \mathrm{~g}$ & $0.03 \mathrm{~g}$ \\
Nipagin & $0.01 \mathrm{~g}$ & $0.01 \mathrm{~g}$ & $0.01 \mathrm{~g}$ \\
Nipasol & $0.08 \mathrm{~g}$ & $0.08 \mathrm{~g}$ & $0.08 \mathrm{~g}$ \\
Oleum Jasmine & $5.43 \mathrm{ml}$ & $5.72 \mathrm{ml}$ & $5.43 \mathrm{ml}$ \\
Distilled water & &
\end{tabular}

\subsection{Evaluation of Ethanolic Extract of Mangosteen Pericarp Cream Dosage Form}

Type of the creams was determined by washing the formulae with water, then the amount of water needed to wash were recorded. Organoleptic examination of creams included observations of homogeneity, color and odor. Observations were done whether there were differences of homogeneity, color and odor in the cream preparations during 2 weeks of storage. The $\mathrm{pH}$ values of the formulae were measured at storage duration of week 0,1 and 2 .

\section{Results}

\subsection{Determination of Mangosteen}

Based on the result of determination which was performed by the Laboratory of Physiology, Faculty of Mathematics and Natural Sciences Mulawarman University, it showed that the sample was a species of Garcinia mangostana L., Clusiaceae family, and has Indonesian name Manggis.

\subsection{Extraction of Mangosteen Pericarp}

Heavy thick extract obtained from $533 \mathrm{~g}$ of crude mangosteen pericarp was $25.4 \mathrm{~g}(23.53 \%)$. The extract obtained was brown, viscous, and bitter. Result of the evaluation of the ethanolic extract of mangosteen pericarp cream produced is shown in Table 2.

Table 2. Results of the Determination of The Cream Type

\begin{tabular}{cl}
\hline Formula & Water required \\
\hline I & $8.2 \mathrm{ml}$ \\
II & $7.6 \mathrm{ml}$ \\
III & $6.8 \mathrm{ml}$ \\
\hline
\end{tabular}


From the test results of the three formulae, it was found that $0.5 \%$ cream with extract could be washed with $8.2 \mathrm{ml}$ of water, the second formula containing $1.5 \%$ extract was able to be washed with $7.6 \mathrm{ml}$ of water, while the last formula containing $4.5 \%$ extract needed $6.8 \mathrm{ml}$ of water to be washed completely. Organoleptic of the cream formulas is demonstrated in Table 3.

Table 3. Organoleptic Observations During 2 Weeks of Storage

\begin{tabular}{|c|c|c|c|c|c|c|c|c|c|}
\hline \multirow[t]{2}{*}{ Observation } & \multirow[t]{2}{*}{ Formula } & \multicolumn{8}{|c|}{$\begin{array}{c}\text { Change Over Time Storage } \\
\text { (in day) }\end{array}$} \\
\hline & & 0 & 2 & 4 & 6 & 8 & 10 & 12 & 14 \\
\hline \multirow{4}{*}{ Homogeneity } & $\mathrm{F} 1$ & - & - & - & - & - & - & - & - \\
\hline & $\mathrm{F} 2$ & - & - & - & - & - & - & - & - \\
\hline & F3 & - & - & - & - & - & - & - & - \\
\hline & $\mathrm{F} 1$ & - & - & - & - & - & - & - & + \\
\hline \multirow{2}{*}{ Color } & $\mathrm{F} 2$ & - & - & - & - & - & - & - & + \\
\hline & F3 & - & - & - & - & - & - & - & - \\
\hline \multirow{3}{*}{ Odor } & $\mathrm{F} 1$ & - & - & - & - & - & - & - & - \\
\hline & $\mathrm{F} 2$ & - & - & - & - & - & - & - & - \\
\hline & F3 & - & - & - & - & - & - & - & - \\
\hline $\begin{aligned} \mathrm{F} 1 & =\text { Form } \\
- & =\text { no ch }\end{aligned}$ & & & & & & & $F$ & 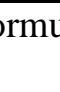 & \\
\hline
\end{tabular}

Organoleptic examination of the creams including the observations of homogeneity, color and odor. Observations were done to examine whether there were differences in homogeneity, color and odor of the cream preparations during 2 weeks of storage. Based on the table 3, it can be seen that the cream showed slight changes in the third week of storage. In the third week of storage, the colors of the F1 and F2 creams began to fade if compared to the initial formulations. Result of pH Evaluation (Acidity) is shown in Table 4.

Table 4. Results of $\mathrm{pH}$ Evaluation

\begin{tabular}{cccc}
\hline & \multicolumn{3}{c}{ Storage Duration } \\
\cline { 2 - 4 } Formula & Week 0 & Week 1 & Week 2 \\
\hline F1 & 6 & 6 & 6 \\
F2 & 6 & 6 & 6 \\
F3 & 6 & 6 & 6 \\
\hline
\end{tabular}

Spreadability of the produced creams is shown in Table 5. Based on test results of dispersive power as shown in Table 5, it can be seen that the formula I with a fairly high consistency gave the small diameter which were different from the formulae II and III. Formulae II and III had a lower viscosity than the formula I which allowed the preparations easily to flow and spread. 
Table 5. Diameter Coverage at Week 0 and Week 1

\begin{tabular}{cccc}
\hline Treatment & Formulae & $\begin{array}{c}\text { Diamater } \\
(\mathbf{m m}) \\
\text { week 0 }\end{array}$ & $\begin{array}{c}\text { Diamater } \\
(\mathbf{m m}) \\
\text { week 1 }\end{array}$ \\
\hline \multirow{2}{*}{ No load } & $\mathrm{A}$ & 3.65 & 3.85 \\
& $\mathrm{~B}^{*}$ & 4.9 & 4.8 \\
\multirow{3}{*}{ Load } & $\mathrm{C}^{*}$ & 4.75 & 5.3 \\
& $\mathrm{~A}$ & 4.52 & 4.7 \\
& $\mathrm{~B}^{*}$ & 5.22 & 5.67 \\
& $\mathrm{C}^{*}$ & 5.43 & 6.51 \\
\hline
\end{tabular}

Antibacterial Activity of Mangosteen Pericarp Ethanolic Extract Cream against Staphylococcus epidermidis is demonstrated in Table 6. The formation of clear area around the paper disc on the antibacterial activity test proved that the ethanolic extract of mangosteen pericarp formulated in cream dosage forms had antibacterial properties against Staphylococcus epidermidis.

Table 6. Results of Measurement of Inhibition Zone against Staphylococcus epidermidis

\begin{tabular}{ccccc}
\hline & \multicolumn{4}{c}{ Inhibition Zone Diameter $(\mathbf{m m})$} \\
\cline { 2 - 5 } Repetition & F1 & F2 & F3 & K1 \\
\hline I & 0 & $3.5 \pm 2.08$ & $6 \pm 0.5$ & 0 \\
II & 0 & $7.5 \pm 2.08$ & $6.5 \pm 0.5$ & 0 \\
III & 0 & $4.5 \pm 2.08$ & $5.5 \pm 0.5$ & 0 \\
Average & 0 & $5.2 \pm 2.08$ & $6 \pm 0.5$ & 0 \\
\hline
\end{tabular}

F1: cream with extract concentration of $0.5 \%$

F2: cream with extract concentration of $1.5 \%$

F3: cream with extract concentration of $4.5 \%$

K1: negative control

Based on the data showed in the Table 6, it can be seen that the cream with $1.5 \%$ and $4.5 \%$ of extract were able to inhibit the growth of Staphylococcus epidermidis.

\section{Discussions}

In the third week of storage, the colors of the F1 and F2 creams began to fade as compared to the initial formulations (Table 3). The color changes that occurred can be caused by adeps lanae. Adeps lanae is susceptible to autoxidation during storage [9]. This autoxidation process can usually cause a rancid odor and unpleasant color [10]. In addition, lack of preservative concentration is also able to cause a color change due to the contamination of microorganisms. The obtained $\mathrm{pH}$ values of the cream formulations were still considered met the requirement for using on the face, the $\mathrm{pH}$ should be 4.5-8 [11]. An over acidic $\mathrm{pH}$ can cause irritation, while over alkaline $\mathrm{pH}$ can cause scaly skin.

Based on the data showed in Table 6 , it can be seen that the cream with $1.5 \%$ of the extract were able to inhibit the growth of Staphylococcus epidermidis. The results of the identification of chemical compounds of mangosteen pericarp, the compounds which have antibacterial activities 
were saponins, tannins, and flavonoids [12]. Poeloengan et al (2010), stated that saponin is an active substance that can increase membrane permeability resulting cell hemolysis, when saponins interact with germ cells, the bacteria will be lysed. Saponins also contain substances that can lyse blood [8]. It is known that red blood cell membrane resembles cell membrane in bacteria so that the processes occured in bacterial cells by saponins are the same as those in red blood cells [13].

The other chemical content of mangosteen percarpare flavonoids which play roles as growing regulator, photosynthesis regulator, antimicrobial agent, and antivirus. Research on the relationship between the flavonoid structure and antibacterial activity indicates their relationship [14]. Flavonoids are able to interfere extracellular proteins affecting the integrity of bacterial cell membranes, as well as coagulant proteins [15].

Tannin compounds found in the skin of the mangosteen fruit is also efficacious as antibacteria. The toxicity of these compounds can damage the cell membrane of bacteria, whereas the astringent tannin compound can induce the formation of bonding compound complexes with microbial enzymes or substrates and the formation of a tannin bonding complex with metal ions that can increase the toxicity of the tannin. In addition, tannin can shrink the cell wall or cell membrane so that interferes the permeability of the cell, which ultimately causes the cell can not perform life activities so that the growth is hampered or even death. Tannin is also able to react on cell membranes, inactivate enzyme, and inactivate fungi genetic material [15].

\section{Conclusion}

The results showed that the ethanolic extract of mangosteen pericarp (Garcinia mangostana L.) can be formulated inantiacne cream dosage form. Cream formulae II and III were effective against Staphylococcus epidermidis which produced inhibition zone diameter values of $5.62 \mathrm{~mm}$ and $6 \mathrm{~mm}$, respectively. The cream dosage form that meet the best physical properties is shown by the formula II.

\section{REFERENCES}

[1] H.Halim, and W. Sambijono, "Management of Acne Vulgaris". Cermin Dunia Kedokteran, p 29-37. 1986.

[2] U.Sukatta, P. Rugthaworn, P. Pitpiangchan, U. Dilokkunanant, "Development of mangosteen anti-acne gel”. Kasetsart Journal-Natural Science. Vol.42, no.5, pp.163-168. 2008

[3] T. Mitsui, "New Cosmetic Science". Amsterdam-Netherlands: Elsevier Science B, p 119. 1997.

[4] M. T. Chomnawang, S. Surassmo, V. S. Nukoolkarn, and W. Gritsanapan, "Antimicrobial effects of Thai medicinal plants against acne-inducing bacteria," Journal of Ethnopharmacology, vol. 101, no. 1-3, pp. 330-333, Oct. 2005. 
[5] M. T. Chomnawang, S. Surassmo, V. S. Nukoolkarn, and W. Gritsanapan, "Effect of Garcinia mangostana on inflammation caused by Propionibacterium acnes," Fitoterapia, vol. 78, no. 6, pp. 401-408, Sep. 2007.

[6] W. Pothitirat, W. Gritsanapan, "Thin-Layer Chromatography-Densitometric Analysis ofMangostin Content in Garcinia mangostana Fruit Rind Extracts". Journal of AOAC International. Vol. 91 no. 5, pp. :1145-1148, Sep. 2008

[7] Departemen Kesehatan RI, Galenic preparations, Departemen Kesehatan RI, Jakrata, pp. 3,7, 10-11. 1986

[8] M. Poeloengan, P. Praptiwi, "Antibacterial activity of Garcinia mangostana L pericarp", Media Penelitian dan Pengembangan Kesehatan, vol. 20, Jun. 2010

[9] R.C. Rowe, P.J. Sheskey, P.J. Weller, Handbook of pharmaceutical excipients. Pharmaceutical press, London, 2006.

[10] H.A. Lieberman, L. Lachman L, J.B. Schwart, The Theory and Practice of Industrial Pharmacy, p 1.1989

[11] S.N. Indonesia. Sun block preparation, SNI 16-4399-1996.. Badan Standardisasi Nasionalm, Jakarta page 7; 1996.

[12] Supomo, E. Siswanto, and Rukmana "Antibacterial activity of ethanolic extract of Garcinia mangostana L pericarp against Staphylococcus epidermidis ATCC 49461", Jurnal Ilmu Kesehatan, vol. 2, no. 3, pp. 159-165. 2015.

[13] P.K. Wardani, "Phytochemical analysis of biochemical compounds of ethanolic extract of Shorea smithiana Symington leaf and its antibacterial against Staphylococcus aureus and Escherichia coli", Theses, Universitas Mulawarman, Indonesia, 2012.

[14] T. P. T. Cushnie and A. J. Lamb, "Antimicrobial activity of flavonoids," International Journal of Antimicrobial Agents, vol. 26, no. 5, pp. 343-356, Nov. 2005.

[15] T. Hartanto, "Antimicrobial activity of Garcinia mangostana L. pericarp extract against growth of Shigella dysentriae In Vitro". Theses, Fakultas Kedokteran Universitas Islam Sultan Agung, Semarang. 2013. 